\title{
É NECESSÁRIO, POSSÍVEL E MUITO GOSTOSO, ABRIR BRECHAS NO IMPOSSÍVEL
}

\author{
Apoliana Regina Groff \\ Universidade Regional de Blumenau e Centro de Defesa dos Direitos Humanos de Blumenau, \\ Blumenau, Brasil \\ Josiele Bené Lahorgue \\ Centro de Defesa dos Direitos Humanos de Blumenau, Blumenau, Brasil
}

Falar sobre Sílvia Lane é expressar sentimentos acerca de um momento em nossas vidas onde compreendemos a real importância de se produzir uma ciência psicológica comprometida com a realidade brasileira e latinoamericana, trabalhando para a libertação de um povo sempre marcado pela desigualdade e pela miséria, tanto material quanto conceitual.

Nosso contato com a teoria de Sílvia se deu em sala de aula, quando na leitura de seu livro, O que é Psicologia Social, solicitada por um professor, em uma disciplina da graduação. No entanto, ao iniciarmos a militância no Movimento Estudantil tivemos maior aproximação com a Sílvia professora, pesquisadora e militante. A partir desse momento tivemos a compreensão de que sua teoria não é apenas uma teoria em Psicologia, mas sim, uma teoria que reflete um comprometimento com a real transformação da sociedade brasileira e latino-americana e reflete também a dedicação de toda uma vida em busca de elementos capazes de construir relações opostas ao individualismo, pautadas no coletivo e em valores como a solidariedade e a cooperação.

Por termos em nossa atuação, enquanto militantes e dirigentes de uma entidade estudantil, uma postura crítica em relação à formação acadêmica e atuação profissional, desejávamos contribuir no processo de consciência de muitos de nossos colegas e, para isso, surgiu a idéia de deixarmos registrado, na história do Curso de Psicologia da Fundação Universidade Regional de Blumenau (FURB), a importância que Sílvia tem, pelo vigor de suas idéias, pelo seu carisma, sua criatividade, pela sua radical opção ético-política, pela sua postura crítica e por ser grande incentivadora de gerações de psicólogos envolvidos com a produção de uma psicologia na qual se articulam teoria e prática como elementos indissociáveis.

Surgiu, neste momento, a idéia de um diálogo com a professora Sílvia Lane e a realização de uma homenagem para a mesma. Sabendo dos problemas de saúde que Sílvia enfrentava na época, temíamos que sua pre- sença não fosse possível e, por este motivo adiamos a data prevista para o evento, aguardando que Sílvia se recuperasse de uma cirurgia a qual tinha se submetido na época.

Enquanto esperávamos a recuperação de Sílvia, debatíamos sua ida para Blumenau e uma evidência se tornava cada vez mais forte; que um diálogo assim qualificado implicava que também precisávamos nos falar e nos ouvir. Então, a idéia inicial de uma palestra se transformava em uma atividade capaz de permitir o necessário exercício de expressão de nossas produções em Psicologia Social, fazendo nascer assim a I Jornada de Psicologia Social da FURB.

Sílvia se fez presente em nosso evento, onde foi homenageada, ficando seu nome registrado no Centro Acadêmico que passou a se chamar Centro Acadêmico de Psicologia Sílvia Lane. Muito mais do que o registro do seu nome em uma entidade estudantil, Sílvia nos ensinou a importância do comprometimento que devemos ter com a vida das pessoas.

Sílvia deixou a vida, não a psicologia. Mesmo após sua despedida continuou a nos ensinar que é preciso valorizar, amar, admirar as pessoas e, sobretudo, dizer a elas o quanto são queridas. Felizmente tivemos a oportunidade de demonstrar a admiração e o carinho pela professora Sílvia, meses antes de sua despedida.

Fica registrada em nossas histórias a capacidade que Sílvia teve de nos fazer refletir acerca de nossa formação e, a capacidade que ela teve de nos fazer sonhar com a possibilidade de uma sociedade melhor. Com certeza a professora, a pesquisadora e a militante Sílvia está e estará sempre presente em nossos corações e em nossa atuação enquanto profissionais da Psicologia.

Não poderíamos deixar de finalizar este texto, sem a presença de Sílvia, pois esta estará sempre viva na vida daqueles que tiveram a oportunidade de conhecê-la pessoalmente, como na vida daqueles que virão a conhecêla durante o diálogo com ela em suas leituras. 
“. . . Somos a consciência que reflete o mundo e somos afetividade que ama e odeia este mundo, e com esta bagagem nos identificamos e somos identificados por aqueles que nos cercam" (Lane, 1995, p. 62). ${ }^{1}$

Diretório Acadêmico Sílvia Lane. Suas idéias e gestos continuam fecundando o solo sedento de nossa América Latina.

\section{Notas}

1. Lane, S. T. M. (1995). A mediação emocional na construção do psiquismo humano. In S. T. M. Lane \& B. Sawaia (Eds.), Novas veredas da Psicologia Social. São Paulo, SP: Brasiliense.
Apoliana Regina Groff é estudante da $9^{\mathrm{a}}$ fase do Curso de Psicologia da Universidade Regional de Blumenau e Secretária de Formação do Centro de Defesa dos Direitos Humanos de Blumenau. Endereço para correspondência: Universidade Regional de Blumenau, Rua Antônia da Veiga, 140; Blumenau, SC, 89012-900. apoliana10@yahoo.com.br

Josiele Bené Lahorgue é psicóloga, formada pela Universidade Regional de Blumenau e Coordenadora Geral do Centro de Defesa dos Direitos Humanos de

Blumenau.

psicojosi@terra.com.br 